\title{
Attitudes of Students at a Private Christian Liberal Arts University Toward the Teaching of Evolution
}

\author{
Troy A. Ladine
}

Published online: 30 July 2009

(C) Springer Science + Business Media, LLC 2009

\begin{abstract}
Students at private Christian colleges tend to have a viewpoint that incorporates faith and belief in God. Whether due to misconceptions about evolution, lack of knowledge of the nature of science, or belief that their faith cannot allow them to accept evolution, there tends to be a great deal of confusion about evolution. This study investigates the attitudes toward evolution of students at a small Christian liberal arts university located in east Texas (East Texas Baptist University, ETBU) and how they would feel most comfortable being approached about evolution in the college science classroom. The majority of students at ETBU are from either Texas or Louisiana. In high school, both states require at least one science course to be taken and evolution to be taught at some level of understanding. Students show a fair understanding that science includes only naturalistic explanations $(\bar{x}=2.16 \pm 0.68)$. However, a greater number of science courses and maturity level of the student resulted in significant differences $(P=0.0001$ and $P=0.002$, respectively) in the understanding of science. Nevertheless, there was a general assertion that God should be included in the definition of science by the majority of students (64.4\%), indicating a misunderstanding of the nature of science. Students responded that they would be most comfortable with being approached in the classroom about evolution through the presentation of the science supporting evolution (19.6\%), and being shown how creationism and intelligent design are not science (29.8\%). A number of students responded that the professor should accept creationism and intelligent design as science and
\end{abstract}

T. A. Ladine $(\bowtie)$

Department of Biology, East Texas Baptist University,

1209 N Grove,

Marshall, TX 75670, USA

e-mail: tladine@etbu.edu teach them as such (38.2\%). This paper will present methods to address students that respond to evolution in this manner.

Keywords Evolution · College education . Nature of science $\cdot$ Intelligent design $\cdot$ Creationism

\section{Introduction}

Many students at private Christian universities come in with numerous misconceptions about evolution or have not been taught the subject in high school. Along with the misconceptions about evolution, a majority of students appear to have an apprehension towards the subject. Having taught general education courses for the past 8 years at a private Christian university in east Texas, I have encountered firsthand many of these misconceptions about evolution (see Isaak 2003, Cunningham and Wescott 2009) and the nature of science (see McComas 1996) as well as student apprehension toward the two subjects.

Numerous statements from religious organizations (Central Conference of American Rabbis, Pope John Paul II, Clergy letter project (2008) signed by over 11,000 Christian clergy) and religious scientists (Francis Collins, Kenneth Miller, Father George Coyne; listed in National Academy of Science and Institute of Medicine 2008) have noted there should be no contradiction between the science and religion. That the controversy still exists may be in part due to the rejection of natural scientific explanations by creationists and interjection of supernatural explanations by creationists and the intelligent design movement. Some may also be due to the lack of understanding of science. The Central Conference of American Rabbis (1984) has stated that ignorance about evolution will seriously under- 
mine understanding of the world, and introduction of explanations other than evolution in biology classes will give a false sense of scientific methods. The Clergy Project Letter Project stated that rejection of evolution or treating it as "one theory among others" is the same as embracing scientific ignorance and the transmission of scientific ignorance to our children. These are strong statements supporting the understanding of the nature of science and evolution.

The misunderstanding of evolution may be traced to two distinct, but possibly related, features: (1) belief that evolution contradicts the Bible and goes against faith or (2) a lack of understanding of the nature of science. Because most students at East Texas Baptist University (ETBU) are from a Baptist background, they have grown up hearing that evolution contradicts the Bible and hence compromises their faith. Additionally, most have heard incorrect statements about evolution (e.g., evolution is responsible for the uprising of the Nazi regime, eugenics, evolution implies atheism, misconceptions about common ancestry). When starting my lecture series on evolution, I would poll the students on several misconceptions of evolution (see Isaak 2003), how evolution operates through natural selection, and the definition of evolution. Students at ETBU exhibited misconceptions at all levels of understanding of evolution. My experience with students at private Christian liberal arts universities and their receptiveness to evolution has been one of mixed reactions. Some will receive the topic with a very open mind, while others will be very blunt in their negativity toward evolution and at being required to listen to a lecture on evolution.

Because the administration at ETBU had received letters negative to the teaching of evolution and I received negative comments on course evaluations, I felt it was necessary to determine an approach that would encourage students with a negative view of evolution to be somewhat more open-minded about evolution. Due to a paucity of information on how to approach students at private Christian liberal arts universities about evolution, the objectives of my study were (1) to investigate student attitudes toward evolution at a private Christian liberal arts university and (2) identify the most comfortable approach for students to learn about evolution in a science class. The goal was to show students that accepting evolution does not violate their faith, but may strengthen it.

\section{Methods}

Three hundred eleven students responded to a 15-question anonymous survey to assess how the student would feel most comfortable learning about evolution in the biology classroom. ETBU is a private liberal arts university affiliated with the Baptist General Convention of Texas. The university is located in a small east Texas community (population ca. 25,000) and has an enrollment of ca. 1,200 students from 43 states and 12 foreign countries. However, the majority of students are from Texas (90\%) and Louisiana (6.3\%). The background of the majority of Texas residents is mixed between a relatively small urban area $(<30,000)$ and the Houston and Dallas metropolitan areas. Enrollment at ETBU is primarily traditional students (79\% of students younger than 21 and 90\% younger than 24). The majority of students enrolled at ETBU list Baptist $(72 \%)$ as their Christian denomination. Fifteen percent of students enrolled at ETBU did not list a denominational preference. No other denomination selected was greater than $3 \%$.

The majority of majors at ETBU are education majors (23\%). Education majors include elementary education and discipline-specific secondary education majors. Business (19\%), religion (15\%), nursing (10\%), and psychology $(6 \%)$ make up the top five majors. Biology is the sixthlargest major at ETBU (5\%).

All students at ETBU are required to take at least one science course, and most students are required to take two science courses as part of the general education requirements. There are two physical science courses and the chemistry courses that do not present evolution. All general education courses taught in biology do present evolution. The general education courses are primarily for the non-major, and most are not taken by biology majors. Biology majors' exposure varies depending on the professors. There is a specific course presenting evolution (Population Biology: BIOL4303) in the biology curriculum. Because of the discrepancy of science courses taken by students at ETBU, evolution may not be encountered by some students in any science course. However, biology majors will encounter evolution to some extent in the majority of their biology courses.

The religion faculty at ETBU incorporates evolution into their discussions on Genesis. Most faculty at ETBU do not dismiss evolution and generally present it as compatible with the Biblical view. There has been one seminar hosted by the religion honors society on campus in the past four years, involving the integration of faith and evolution. Reactions of the students and faculty present at the seminar varied in their acceptance of evolution. All science faculty members at ETBU encourage the discussion of integration of a student's faith with science.

To reach as broad a student population as possible, the survey was administered in selected general education courses at ETBU by the professor teaching the course from 28 January to 10 February 2008. The survey and consent form were approved by the Human Subjects Research Review Committee of ETBU. All participants signed an informed consent form prior to completing the survey. 
The integral question of the survey asked the manner in which the student felt most comfortable being taught evolution: Question 1: if evolution is taught in the biology class you are taking, what approach would you be most comfortable with in hearing about origins of life in a science class? The following responses to this question were available on the form: (1) include only the science supporting evolution; (2) include the science supporting evolution and how evolution affects you; (3) include creationism and intelligent design but show how they are not scientific; (4) the professor should accept creationism and intelligent design as legitimate scientific theories and present them as such; and (5) other (elaborate on how you would like to see evolution approached below). Even though evolution does not include the origin of life, the question was worded in this manner so as to minimize any potential bias students may have. Also, from experience with this student population, it was known that many students believe that evolution and origin of life are synonymous.

Students used a Likert scale to respond to five questions on the survey that investigated their current understanding of science in general and evolution in particular (Table 1). The remaining three questions further investigated the background of the responders, (Table 1) surveying the classification, gender, major, and the number and level of science courses the student had taken. Data was analyzed for each major separately and categorized into groups of biology major (BIO) and non-biology major (NB). Background of the student referred to the number of science courses students had taken. Responses for background were: none, high school science only, one or two college science courses, or three or more college science courses.

Statistical Analyses To determine an average response, I assessed responses to questions 1-6 through calculating the mean response plus or minus one standard deviation for each of the following categories; background, classification, and major (individual majors and BIO and NB). Differences among categories were analyzed using a Kruskal-Wallis rank sum test. Pearson's product correlation was conducted to test for correlations between the approach to teaching evolution and the questions involved with the definition of science and the definition of evolution. All statistical analyses were conducted using $\mathrm{R}$ version 2.41 (R Development Core Team 2006)

\section{Results}

The mean response $(\bar{x}=2.16 \pm 0.68)$ of all students defining science by naturalistic explanations (Question 2) indicates agreement on what constitutes science. Two subcategories, classification $\left(X^{2}=16.81, d f=4, P=0.002\right.$; Fig. 1) and number of science courses $\left(X^{2}=23.05, d f=3\right.$, $P=0.0001$; Fig. 2), indicate that maturity level and science courses in college play a role in this agreement. Freshmen were more likely to disagree with the naturalistic explanation than juniors and seniors. Students with three years of science were more likely to agree with a naturalistic explanation of science than those with only high school science. Students with only high school science and those with one or two college courses showed no difference in agreement with naturalistic explanations. There was no difference between $\mathrm{BIO}$ and NB students on the definition of science $\left(X^{2}=2.54\right.$, $d f=1, P=0.111)$ when the non-majors were combined. However, there was a significant difference in the definition of science across various majors $\left(X^{2}=43.47, d f=20, P=\right.$ $0.002)$ : math $(\bar{x}=3.00 \pm 0.81)$, chemistry $(\bar{x}=2.50 \pm$ $0.55)$, kinesiology $(\bar{x}=2.38 \pm 0.65)$, and English $(\bar{x}=$ $3.00 \pm 0.71)$, with majors averaging greater than 2.3 on their responses indicating a tendency to disagree with a naturalistic explanation for observations. Nevertheless, $64.4 \%$ of students responded in agreement that God should be included in the definition of science (Question 3). There were no categories approaching significance in differing in this category (Background- $-X^{2}=1.45, d f=3, P=0.694$; Major $-X^{2}=20.65, d f=1, P=0.773$; Classification $-X^{2}=0.581$, $d f=4, P=0.965)$.

Responses to the definition of evolution (Question 5) indicated some general knowledge of evolution. The number responding with the correct definition was $37.6 \%$, with $8.5 \%$ indicating the origin of the universe, $16.7 \%$ the origin of life. However, $37.3 \%$ of responses indicated no knowledge pertaining to the definition of evolution. Knowledge of the definition of evolution differed significantly for two categories: classification $\left(X^{2}=10.176, d f=4, P=0.038\right.$; Table 2) and science background $\left(X^{2}=23.068, d f=3, P=\right.$ 0.00004; Table 2). Seniors were more likely to respond with the correct definition of evolution than freshmen. Students with three or more college courses were more likely to respond with the correct definition than all other groups. Biology majors were more likely to respond with the correct answer than non-biology majors $\left(X^{2}=4.988, d f=1, P=0.026\right.$; Fig. 3). The majority of students $(89.0 \%)$ responded that God played a role in the creation of all organisms compared with an intelligent designer (9\%), or God was not involved in the creation of all organisms (1.0\%; Question 6).

There was an interesting split in students' preferences for the presentation of evolution (Question 1). Approximately half indicated a preference for either "including the science supporting evolution and showing how evolution affected them" (84 responses), or "including creationism and intelligent design but showing how the two are not science" (82 responses). However, 34\% responded that the professor 
Table 1 Questions asked on a survey including the potential responses of students at East Texas Baptist University regarding attitudes to evolution and how best to approach evolution in the biology classroom. Questions 2 and 3 used a Likert scale for responses

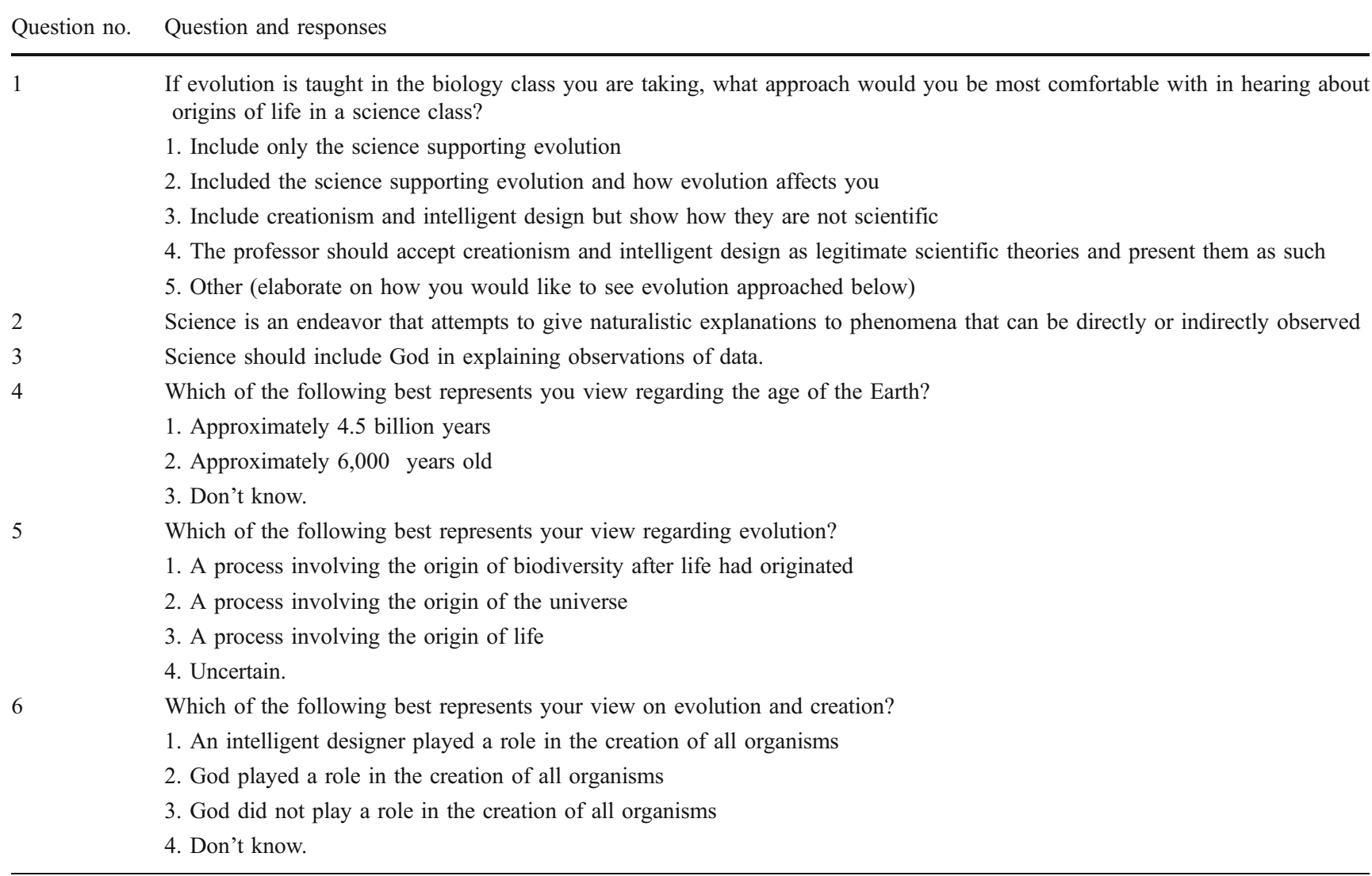

should accept creationism and intelligent design as legitimate theories and teach them in that manner. The remaining 31 responses inserted another approach or information relating to their negative views on evolution. No category differed significantly in how evolution should be approached in the classroom. The approach to the teaching of evolution showed a correlation

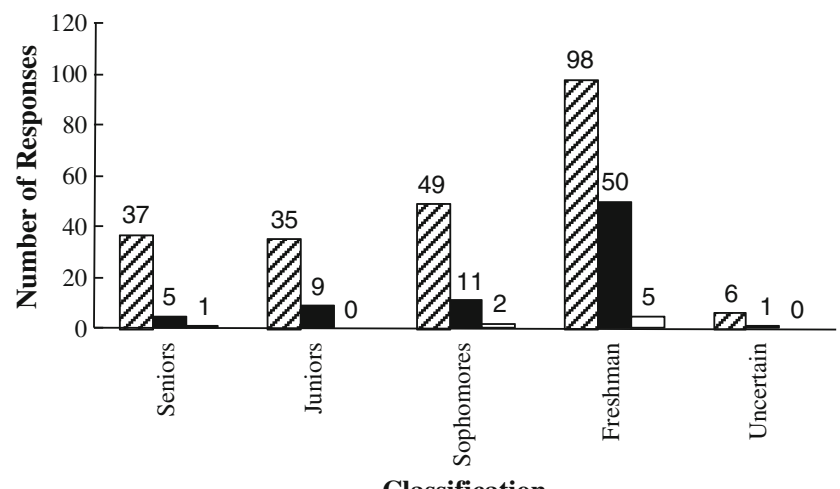

Fig. 1 Number of students responding to the definition of science as having only a naturalistic explanation by class level of the student. Responses are; agree (slashed bars), neutral (filled bars), and disagree (white bar) between the definition of evolution $(r=0.147)$ and the definition of science $(r=0.200)$.

\section{Discussion}

Upper-division students at East Texas Baptist University have generally taken at least one science class (most majors require two science courses), with some degree of variation in the presentation of the nature of science. Data of this

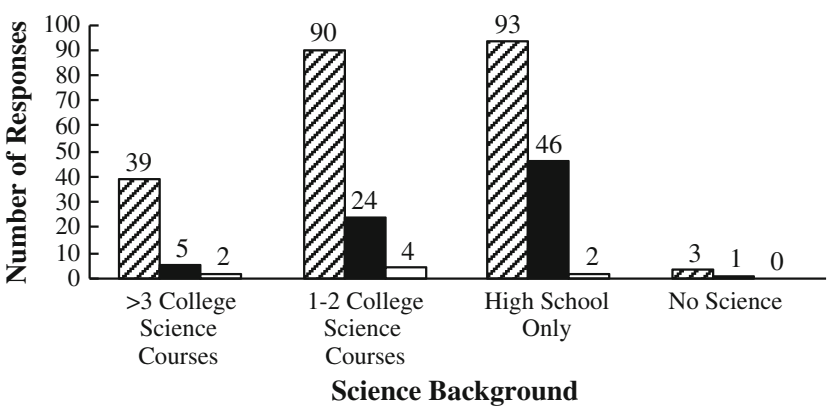

Fig. 2 Percentage of students responding to the definition of science as having only a naturalistic explanation by the number of science courses they have taken. Responses are; agree (diagonal slashes), neutral (solid), disagree (white) 
Table 2 Number of responses to the definition of evolution according to class level and number of science courses a student has taken
${ }^{\text {a }}$ Origin of biodiversity after life had originated on the Earth

${ }^{\mathrm{b}}$ Origin of life on the planet

${ }^{c}$ Origin of the universe

\begin{tabular}{|c|c|c|c|c|c|}
\hline \multirow[t]{2}{*}{ Class } & \multirow[t]{2}{*}{ Background } & \multicolumn{4}{|c|}{ Number of responses for the definition of evolution } \\
\hline & & Biodiversity $^{\mathrm{a}}$ & Life $^{\mathrm{b}}$ & Universe $^{c}$ & Don't know \\
\hline \multirow[t]{4}{*}{ Senior } & $>3$ & 10 & 5 & 0 & 0 \\
\hline & $1-2$ & 11 & 5 & 0 & 0 \\
\hline & High & 2 & 1 & 0 & 0 \\
\hline & None & 0 & $0 \mathrm{k}$ & 0 & 0 \\
\hline \multirow[t]{4}{*}{ Junior } & $>3$ & 7 & 2 & 0 & 3 \\
\hline & $1-2$ & 11 & 3 & 1 & 11 \\
\hline & High & 0 & 2 & 0 & 2 \\
\hline & None & 0 & 0 & 0 & 1 \\
\hline \multirow[t]{4}{*}{ Sophomore } & $>3$ & 7 & 1 & 1 & 2 \\
\hline & $1-2$ & 10 & 4 & 4 & 6 \\
\hline & High & 9 & 3 & 2 & 12 \\
\hline & None & 0 & 0 & 0 & 1 \\
\hline \multirow[t]{4}{*}{ Freshman } & $>3$ & 4 & 0 & 0 & 0 \\
\hline & $1-2$ & 10 & 5 & 5 & 22 \\
\hline & High & 29 & 21 & 10 & 42 \\
\hline & None & 0 & 0 & 0 & 2 \\
\hline \multirow[t]{4}{*}{ Uncertain } & $>3$ & 1 & 0 & 0 & 1 \\
\hline & $1-2$ & 1 & 1 & 0 & 0 \\
\hline & High & 2 & 1 & 0 & 0 \\
\hline & None & 0 & 0 & 0 & 0 \\
\hline
\end{tabular}

study show the more college science courses a student completes the better the understanding a student has of what constitutes science (but, see Nehm and Schonfeld 2007). While, in itself, an understanding of what constitutes science may not lead to an understanding or acceptance of evolution, the knowledge that science requires naturalistic explanations may aid in alleviating some misconceptions of science: e.g., (1) that science has to adhere to an identical set and sequence of steps (i.e. the scientific method; (McComas 1996), and (2) that theories are simply laws that have not been fully tested (Horner and Rubba 1979). The second of these is one of the concerns that I address in

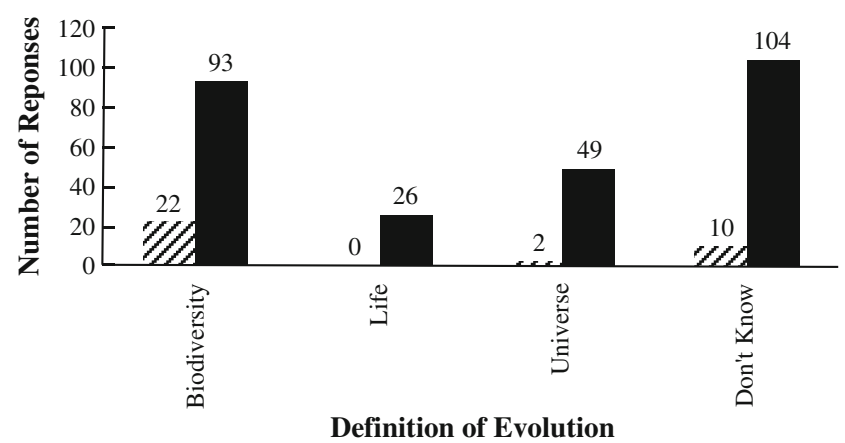

Fig. 3 Number of students responding to the definition of evolution according to grouping of biology majors (diagonal slashes) and nonbiology majors (solid fill) my classes: "evolution is only a theory." I stress that a scientific theory is not the same as the theory the student may be used to hearing. Stressing that a scientific theory is a testable and falsifiable explanation and how the inclusion of a non-naturalistic explanation places the explanation outside of science is where I begin.

The National Academy of Science and Institute of Medicine (2008, page 10) has defined science as "The use of evidence to construct testable explanations and predictions of natural phenomena, as well as the knowledge generated through this process." Students at ETBU generally accepted a naturalistic explanation for science; nevertheless, they responded that God should be included in the definition of science. I feel this indicates a general misunderstanding of what is to be considered naturalistic. To reinforce the naturalistic explanation as a testable explanation in classes where I teach evolution, I show how evolution is testable. While including God as a cause for any scientific phenomena makes a hypothesis untestable, I do not attempt to discredit the students' belief in God while showing that including God in the explanation makes an untestable hypothesis. Because discrediting the student's beliefs may have the adverse affect of causing the student to disregard aspects of scientific investigation (see Plantinga, 2008; Robinson 2005), one goal of my teaching about the nature of science is to teach the student that science is limited to naturalistic explanations. I show the 
students how inclusion of God makes an untestable statement through the use of a thought game. I ask to students to determine what I am thinking at the time. Of course, there is no way to test this, as there is no way to test the thinking of God when applied to evolutionary thinking.

Slightly over one third of all students responded correctly to the definition of evolution. This appears to be in contrast to the findings of other surveys that belief and acceptance of evolution are negatively correlated (Hobin 2008; Nehm and Schonfeld 2007; Reading the polls on evolution and creationism 2008). However, the results of my study merely suggest that students have been introduced to evolution and remember the definition while retaining their belief in creationism. Evolution is required to be taught in Texas and Louisiana. Both states received a " $C$ " in the evaluation of how evolution is covered in high school in earlier assessments (Aguillard 1999; Moore 1999; Shanker and Skoog 1993) and have not improved since (National Center for Science Education 2008). The findings of my study indicate that the more college courses one has taken, the more likely a correct response to the definition of evolution and that biology majors were more likely to respond correctly than non-biology majors. Because evolution is a major cornerstone of biology, it is discussed in most biology courses. Thus, in the groups that were more likely to respond correctly, there was a greater emphasis on science, and to some degree, evolution. Therefore, I believe the responses are best interpreted as the misunderstanding of the nature of science.

This survey indicates that most students are open to hearing about evolution as long as it is taught in the proper setting. For the students that feel evolution contradicts their faith teachings, that means (1) discussing the science supporting evolution (Alles 2001; Cherif et al. 2001; Farber 2003; McComas 1994; National Academy of Science and Institute of Medicine 2008) and (2) showing how intelligent design and creationism are not valid scientific theories. For the student, acceptance of evolution starts with a knowledge of the correct definition of science and an understanding of testable and untestable hypotheses. A good background in the nature of science will allow the student to critically determine the difference between good science and pseudoscience. Obviously, this may not work for all students. The study's correlations between the definition of science and the definition of evolution with the approach to teaching evolution, although weak, indicate that an improved understanding of the nature of science should improve the acceptance of evolution.

Approaching students that have a great belief in God can be difficult at times. I have had students question the teaching of evolution at a Baptist University. Responses on the survey stated included statements such as "God created the earth so live with ....", "It (evolution) is foolishness and
I already know God is the creator." My approach to teaching evolution is one of dialogue and debate about how evolution is science and of showing students how their faith is not compromised. Thus, I have found that if evolution is taught as science and that it can be accepted without giving up belief in God (agreeing with Schneider 2005), some students will come to accept that evolution does not violate their faith and begin to accept evolution. Students have written on their course evaluations, "evolution doesn't take God out of the picture," "evolution doesn't nullify the existence of God," "science does not discredit God," "learning that evolution and religion can coexist," and "I learned that evolution may not really be as much of an evil lie as I have always been taught."

I am not advocating that intelligent design and creationism be considered science, nor should they be taught as science. Nor am I advocating "teaching the controversy," as there is no controversy. Only that, at least in selected college science courses, intelligent design and creationism should be used as tools for the understanding of what constitutes science to increase the understanding and acceptance of evolution.

Acknowledgments I would like to thank the following faculty members who gave class time to administer this survey: Robert Benefield, Justin Briggle, Catherine Cone, Roy Darville, Robert Ellison, Sandy Hoover, Rick Johnson, Israel Natumundi, Carolyn Rester, Kevin Reeves, Melissa Reeves, Darrel Roe, and Don Spencer. I thank the students who responded so honestly concerning a controversial subject. I also thank the anonymous reviewers for their time and constructive comments on previous versions of this manuscript.

\section{References}

Aguillard D. Evolution education in Louisiana public schools: a decade of following Edwards $\mathrm{v}$ Aguillard. Am Biol Teach. 1999;61:182-8.

Alles DL. Using evolution as the framework for teaching biology. Am Biol Teach. 2001;63:20-3.

Central Conference of American Rabbis. On creationism in school textbooks. 1984; http://data.ccarnet.org/cgi-bin/resodisp.pl?file= texts\&year1984 Accessed Dec. 2008.

Cherif A, Adams G, Locher J. What on "earth" is evolution? The geological perspective on teaching evolutionary biology effectively. Am Biol Teach. 2001;63:576-91.

Clergy Letter Project. The Clergy letter-from American Christian Clergy-An open letter concerning religion and science. http:// www.butler.edu/clergyproject/Christian_Clergy/ChrClergy/Ltr. htm. Accessed Dec. 2008.

Cunningham DL, Wescott DJ. Still more "Fancy" and "Myth" than "Fact" in student' conceptions of evolution. Evolution: Education and Outreach. 2009; doi:10.1007/s12052-009-0123-6.

Farber P. Teaching evolution and the nature of science. Am Biol Teach. 2003;65:347-54.

Hobin, J. Evolution and its discontents: a role for scientists in science education. Federation of American societies for experimental biology. 2008;221-4. 
Horner J, Rubba P. The laws-are-mature-theories fable. Sci Teach. 1979;46:31.

Isaak, M. The talk origins archive: five major misconceptions about evolution. 2003; http://www.talkorigins.org/faqs/faq-misconceptionshtml.

McComas, W. investigating evolutionary biology in the laboratory. Reston, VA. National Association of Biology Teachers. 1994.

McComas W. Ten myths of science: reexamining what we think we know about the nature of science. Sch Sci Math. 1996;96:10-6.

Moore R. The courage and convictions of Don Aguillard. Am Biol Teach. 1999;61:166-74.

National Academy of Science and Institute of Medicine. Science, evolution, and creationism. Washington, D.C: The National Academies Press; 2008.

National Center for Science Education. Evolution: how does it fare in state $\mathrm{K}-12$ science standards. 2008; http://ncsweb.org/mcse/20/4/ evolution-how-does-it-fare-state-k-12-science-standards. Accessed Dec. 2008.

Nehm RH, Schonfeld IS. Does increasing biology teacher knowledge of evolution and the nature of science lead to a greater preference for the teaching of evolution in schools? J Sci Teacher Educ. 2007;18:699-723.

Plantinga, Alvin, "Religion and Science", The Stanford encyclopedia of philosophy. Edward N. Zalta (ed.). 2008; http://plato.stanford. edu/archives/win2008/entries/religion-science/.

R Development Core Team. R 2.4.1 - A language and environment. 2006; http://www.r-project.org/.

Reading the polls on evolution and creationism. The Pew Research Center for the People and the Press. Washington D. C. http:// peoplepress.org/commentary/display. php3?AnalysisID $=118$. Accessed Dec. 2008.

Robinson, B. A. Beliefs of Christian faith groups about origins. 2005; http://religioustolerance.org/ev denom1.htm. Accessed Apr 2009.

Schneider, R. J. Essay V: Evolution for Christians. 2005-2007. http:// community.berea.edu/scienceandfaith/essay05.asp. Accessed Apr. 2009.

Shanker G, Skoog GD. Emphasis given evolution and creationism by Texas high school biology teachers. Sci Educ. 1993;77: 221-33. 